\title{
Economic Study the Efficiency of Water Resource Usage (Case Study)
}

\author{
AbdEl Magid H. A. AbdEIMaksoud ${ }^{1}$, Hala H. A. AbdEImaksoud ${ }^{2}$, \\ Mohamed A. M. Moursy ${ }^{1}$ \\ ${ }^{1}$ National Water Research Center. \\ ${ }^{2}$ Department of Agricultural Economics - Faculty of Agriculture - University of Menoufia.
}

\begin{abstract}
The study aims to maximize the utilization of irrigation water. An experiment was conducted at Wadi El-Natroun Research Station - National Water Research Center for reusing fish farms water in irrigating sugar beet, onion, and Alfalfa and comparing the obtained results to that for same cropped plants (as a control) using conventional irrigation water for two successive seasons 2015/2016 and 2016/2017. The results for fish water irrigated crops show an increment in crop yields, fall in costs, reduction in nitrogenous fertilizer consumption due to the dependence on fish wastes that act as source for nitrogenous fertilizer, reduction in soil and outputs heavy elements concentration and consequently better healthy life for humans and animals.
\end{abstract}

Key words: Water use; fish farms; soil fertility; fertilization of fish wastes; heavy elements.

\section{INTRODUCTION}

Fish production significantly contributes to agricultural gross national product. It is considered one of the main sources of providing animal protein to human meal due to its low prices compared to other animal products, as well as the high rate of food conversion of fish compared to other animal products, which estimated at 1.2 for fish and 1.7 for poultry and 2.5 for large animals (Eid 1993). Due to the low productivity of fish yield from seas, natural river and lakes, most fish production is nowadays are obtained from fish farms. This is obvious from the expansion of fish farms establishments in various governorates all over Egypt. The area of fish farms has grown from 264.6 thousand Feddan in 2005 to about 301.6 thousand Feddan in 2015 with an average annual production about $70 \%$ of the average annual fish production during that decade (Fish statistics yearbook 2014 and 2015). There is an urgent need to use water resources as best possible use in all fields, whether in agriculture, industry, navigation or human use, due to the scarcity of the water in Egypt that is considered the main determinant of agricultural development.

\section{Study problem}

Due to scarcity of water resources in Egypt and the expansion of fish farms to cope with the population increase, it would be a waste if fish farms water is not used in crops cultivation to achieve max utilization from water resource. The problem illustrated by the insufficient studies, which dealt with the assessment of the reuse of fish farms water in cultivating agricultural crops. Such waters include fish residuals acting as a bio fertilizer instead of highly priced and environmentally damaging chemical fertilizers, resulting in an increase in harmful residuals in agricultural land, and consequently a decline in agricultural land grading and productivity as well as the spread of harmful diseases that affect humans and animals. In addition to, the increase in production costs.

\section{Objective of the study}

The study aims to maximize the utilization use of water by using fish farms waters in producing different agricultural crops. In addition, benefiting from fish waste as bio fertilizer to overcome the high priced chemical fertilizers and increase returns from crop production. This will increase water use efficiency and return per unit of water.

\section{Research Method}

The study mainly relies on both descriptive and quantitative economic and statistical analysis techniques to estimate income, cost, and economic indicators for study crops. (t) Test is employed to access the difference between productivities using pond water as the sole source for fertilization and chemical fertilizers to produce the same crops using measures of efficiency and profitability for each crop such as Production, Net Income, Relative Profitability, Benefit/Cost Ratio, Return on Invested Pound, Producer Incentive, Value Added and Productivity of water unit (Maxwell 1979). To achieve the study goal, an assessment for fish farms production was compared to total fish production in Egypt, and estimating the amount of water used in these farms and thus estimating the area that can be cultivated using this water. Such cultivated areas were to be converted to organic agriculture with the consequent increase in prices.

\section{Data sources}

The article uses data of an experimental work for integrated fish farming in desert areas at Wadi El-Natroun Research Station - National Water 
Research Center. The experiment was conducted for two seasons 2015/2016 and 2016/2017, where fish pond water was used as a source of irrigation and fertilization only to produce three crops sugar beet, Onion and Alfalfa, compared to adjacent land cultivated with the same crops using normal irrigation water and chemical fertilizers. Soil analysis was carried out in each of these lands to estimate the percentage of residuals in each of these lands. Costs, productivity and other profitability and efficiency measures were estimated for each crop during the two seasons. In addition, the paper employed secondary data obtained from Central Agency for Public Mobilization and Statistics, Ministry of Agriculture and other related theses and research work, which was issued by the National Water Research Center.

\section{DISCUSSION}

1- Fish farms production compared to total fish production in Egypt.

Equation $(1,2)$ in Table (1) showed a statistically significant increase in fish farms production by about 70 thousand ton annually and an annual increase rate of about $8.1 \%$ compared to total fish production In Egypt from its various sources, which statistically significant annual increase by about 67.4 thousand ton and annual increase rate of about $5.5 \%$.

Figure (1) and equation (3) in Table (1) shows the importance of fish farms as source of fish intake in Egypt. This is obvious from the increase of fish farms in Egypt in 2015 to be about 302 thousand feddan compared to nearly 265 thousand feddan in 2005 (excluding rice fields and fish cages). Which indicates a statistically significant increase in fish farms production by about 3.2 thousand feddan annually. The average fish farms production reaches about $70 \%$ of total fish production in Egypt during the period 2005-2015.

Table 1: Trends of fish farms production (earthen ponds) and total fish production in Egypt from 20052015

\begin{tabular}{|c|c|c|c|}
\hline \multicolumn{2}{|c|}{ Coefficients } & $\mathbf{R}^{\prime 2}$ & $\begin{array}{c}F \\
\text { (Calculated) }\end{array}$ \\
\hline $\begin{array}{ll}1- & \text { Governmental and Private Fish } \\
& \text { Production } \\
\end{array}$ & $\begin{array}{l}\mathrm{Y}=446.2+69.6 \mathrm{X} \\
\left(15.4^{* *}\right)\left(16.3^{* *}\right)\end{array}$ & 0.96 & $265.7^{* *}$ \\
\hline 2- Total Fish Production & $\begin{array}{l}\mathrm{Y}=825.2+67.4 \mathrm{X} \\
\left(27.7^{* *}\right)\left(15.3^{* *}\right)\end{array}$ & 0.96 & $235.3^{* *}$ \\
\hline 3- Total Fish Farming Area & 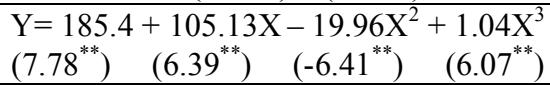 & 0.883 & $17.63^{* *}$ \\
\hline
\end{tabular}

Source: Calculated from data of Agriculture and Land Reclamation Ministry, Fish statistics Yearbook, 2014 \& 2015. ** Significant at $1 \%$

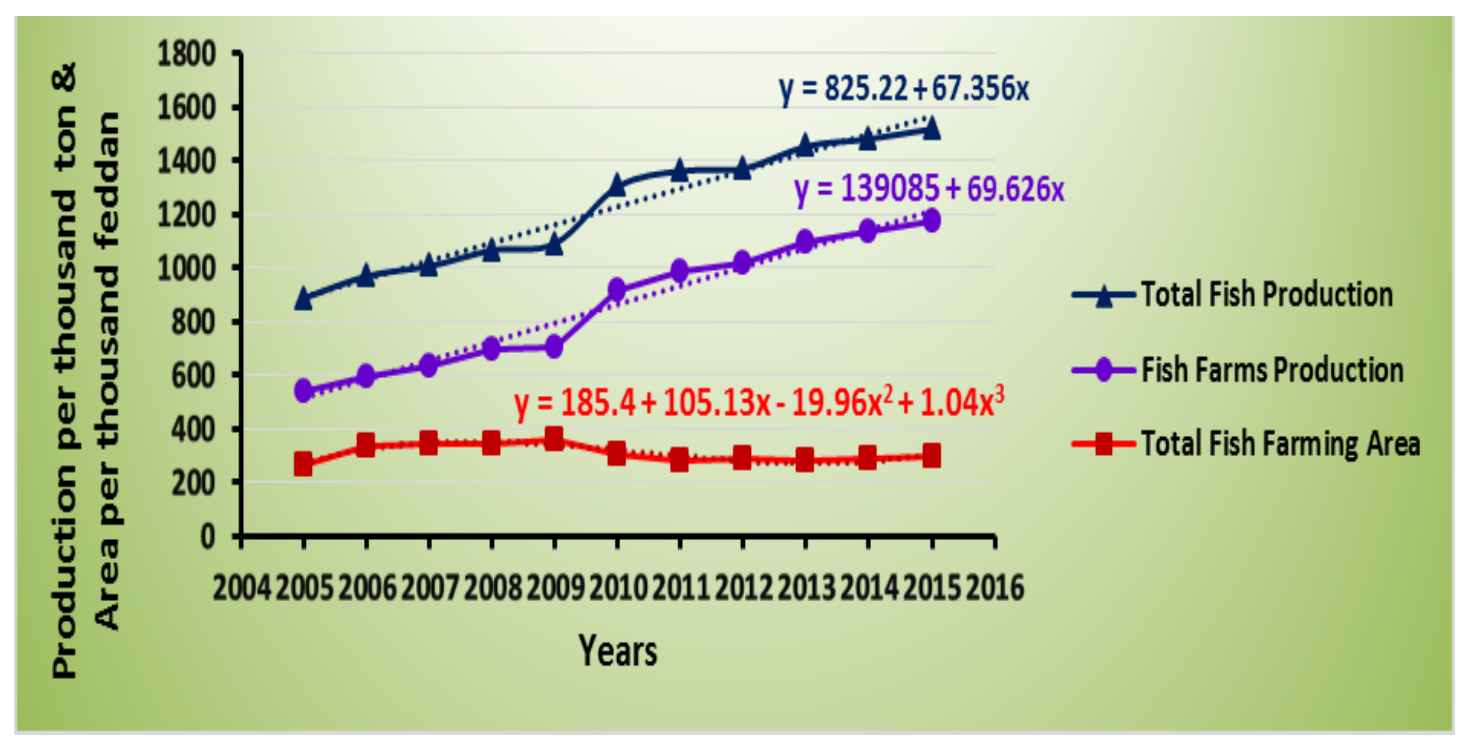

Figure 1: Fish farms area, production and total trends in Egypt through the period 2005-2015 Source: Ministry of Agriculture and Land Reclamation, Fish statistics Yearbook, 2014\&2015. 
2- Average water amount used in fish farms ponds during study period.

The area of public and private fish farms (excluding temporary fish farms area) is 115423 feddan. Excluding roads, sides and side slopes, the average height of water is 1.5 cubic meters. the quantity of required water ${ }^{1}$ for owned and leased public and private fish farms (excluding temporary fish farms area) is estimated to be about 0.455 billion cubic meters., Where the estimated amount of water to be used for fish farms throughout the year is about 13.63 billion cubic meters.

3- Estimating chemical fertilizer quantity saved in case of using fish farms water in irrigation Table (2) showed that, fish farms water estimated at 13.63 billion cubic meters, if used to cultivate sugar beet, Alfalfa and onions it will save about 2.05 million ton of nitrogenous fertilizer estimated at LE 6.15 billion annually. Thus, indicating the importance of reusing fish farms water of to grow agricultural crops.

4- Production and economic indicators for sugar beet, onion and Alfalfa.

Table (3) showed production and some economic indicators of cultivated sugar beet, onion and Alfalfa as follows:

\subsection{For Production:}

There is an increase in average yield for sugar beet, onion and Alfalfa outputs cultivated fishpond water as the sole source of fertilization rather using chemical fertilizers. Which, estimated at about 21.6 ton, 15.3 ton and 38.8 ton for sugar beet, onion and Alfalfa respectively compared to an average about 18.6 ton, 13.2 ton and 29.8 ton respectively using chemical fertilizers. Such statistically significant increase $^{2}$ (3 ton for sugar beet, 2 ton for onion and 9 ton for Alfalfa), represent $16.3 \%, 16.0 \%$ and $30.3 \%$ respectively. This indicates that the productive efficiency of the farms used pond fish water is higher than that used for conventional irrigation water and chemical fertilizers table(3).

\section{2. For Net Income}

Average net income was a statistical significant increased for sugar beet, onion and Alfalfa crops cultivated using fishpond water as the sole source of fertilization rather that cultivated using chemical fertilizers. This average was estimated at about 4,466 LE / Feddan, 20,476 LE / Feddan and 20,525 LE / Feddan for sugar beet, onion and Alfalfa respectively that used fishpond water as a single source of fertilization compared to an average net income for using chemical fertilizers reached about 1,278.3 LE /Feddan, 16,266 LE /Feddan and 13,925

\footnotetext{
${ }^{1}$ Assuming a drainage rate of about $10 \%$ per day and preparing fish ponds for two production cycles require two month

2 (t) Test.
}

LE/Feddan. In other words, there is an increase in average net income for crops used fishpond water which estimated at about 3,188 LE/Feddan, 4,210 $\mathrm{LE} /$ Feddan and 6,600 LE/Feddan for sugar beet, onion and Alfalfa respectively, representing $249.4 \%, 25.9 \%$ and $47.4 \%$ of the average net income of such crops used chemical fertilizers as indicated in table (3).

\subsection{Relative Profitability}

Relative profitability for sugar beet, onion and Alfalfa used fishpond water showed statistically significant increase, which estimated at about $119.5 \%, 347.4$ and $477.2 \%$ respectively compared to that used chemical fertilizer. This indicates that the economic and productivity efficiency of farms used fishpond water, as a single source of fertilization is higher than that used chemical fertilizers in producing such crops as indicated in table (3).

\subsection{Benefit/Cost Ratio:}

Table (3) showed that $\mathrm{B} / \mathrm{C}$ ratios for sugar beet, onion and Alfalfa for experimented farms used fishpond water in irrigation estimated of about 1.74, 4.76 , and 4.11 respectively compared to about 1.19 , 3.67 and 3.02 for those used chemical fertilizers. Which indicating a statistically significant increase of $0.55,1.09$ and 1.09 respectively, i.e., an increment of nearly $46.2 \%, 29.7 \%$ and $36.2 \%$ respectively for crops used fish water pond irrigation compared to chemical fertilizers. This indicates that the economic efficiency of farms used fishpond water, as source of fertilization is higher than that used chemical fertilizers production.

\subsection{Return on Invested Pound}

Return on invested pound results shown in Table (3) depict that sugar beet, onion and Alfalfa cultivated using fishpond water as main source of fertilization estimated at LE 0.74, LE 3.76 and LE 3.11 respectively compared to LE 0.19 , LE 2.67 and LE 2.02 respectively for such crops used chemical fertilizers. In other words, it reached a statistically significant increase about $289.5 \%, 40.8 \%$ and $54.0 \%$ respectively. This indicates the high economic and productivity efficiency of farms used for water fishponds as main source of fertilization than those used chemical fertilizers in the production of such crops.

\subsection{Producer Incentive:}

Producer incentive for cultivating sugar beet, onion and Alfalfa using fishpond water as main source of fertilization was about $42.4 \%, 79.0 \%$ and $75.7 \%$ respectively compared to $16.7 \%, 72.76 \%$ and $66.87 \%$ respectively for those used chemical fertilizers. Such statistically significant increment reached about $156.1 \%, \quad 8.6 \%$ and $13.2 \%$ respectively, 
Table 2: Experiment results for sugar beet, onions and alfalfa during 2015/16 and 2016/17 seasons

\begin{tabular}{|c|c|c|c|c|c|c|}
\hline \multirow{3}{*}{$\begin{array}{c}\text { Item } \\
\text { (feddan) }\end{array}$} & \multicolumn{6}{|c|}{ Crop } \\
\hline & \multicolumn{2}{|c|}{ Sugar beet } & \multicolumn{2}{|c|}{ Onion } & \multicolumn{2}{|c|}{ Alfalfa } \\
\hline & $\begin{array}{c}\text { Fish Water } \\
\text { Irrigation }\end{array}$ & $\begin{array}{l}\text { Conventional } \\
\text { Irrigation }\end{array}$ & $\begin{array}{c}\text { Fish Water } \\
\text { Irrigation }\end{array}$ & $\begin{array}{l}\text { Conventional } \\
\text { Irrigation }\end{array}$ & $\begin{array}{c}\text { Fish Water } \\
\text { Irrigation }\end{array}$ & $\begin{array}{c}\text { Conventional } \\
\text { Irrigation }\end{array}$ \\
\hline Yield (Ton / Fed) & 21.6 & 18.6 & 15.3 & 13.2 & 38.8 & 29.8 \\
\hline$\%$ of Sugar & 19.1 & 17.5 & - & - & - & - \\
\hline Price (LE / Ton) & 487.5 & 430 & 1700 & 1700 & 700 & 700 \\
\hline $\begin{array}{l}\text { Variable Cost } \\
(\mathrm{LE} / \mathrm{Fed})\end{array}$ & 2864 & 3509 & 2249 & 2889 & 1800 & 2100 \\
\hline Rent (LE / Fed) & 3200 & 3200 & 3200 & 3200 & 4800 & 4800 \\
\hline $\begin{array}{l}\text { Water / Feddan } \\
\left(\mathrm{m}^{3}\right)\end{array}$ & 2920 & 2920 & 2480 & 2480 & 2950 & 2950 \\
\hline $\begin{array}{l}\text { Urea Fertilizer } \\
(\mathrm{KG} / \mathrm{Fed})\end{array}$ & - & 250 & - & 200 & - & 100 \\
\hline $\begin{array}{l}\text { Fertilizer Price } \\
\text { (LE / Ton) }\end{array}$ & - & 3000 & - & 3000 & - & 3000 \\
\hline
\end{tabular}

Source: Research experiment data.

Table 3: The average of some production and economic indicators of the research experiment crops in the case of using the water of fish farms and using conventional irrigation, 2015/2016, 2016/2017

\begin{tabular}{|c|c|c|c|c|c|c|}
\hline Crop & Indicator & $\begin{array}{c}\text { Fish } \\
\text { Water } \\
\text { (1) }\end{array}$ & $\begin{array}{c}\text { Conv. } \\
\text { Water } \\
\text { (2) }\end{array}$ & $\begin{array}{l}\text { Diff } \\
(3)\end{array}$ & $\begin{array}{c}\text { \% Change } \\
\text { (4) }\end{array}$ & $\begin{array}{c}T \\
\text { Value }\end{array}$ \\
\hline \multirow{8}{*}{ 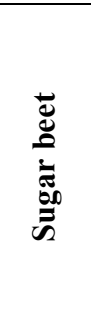 } & Yield/Fed(Ton) & 21.6 & 18.575 & 3.025 & 16.3 & $21.17 * *$ \\
\hline & Net Return (LE/Fed) & 4466 & 1278.25 & 3187.3 & 249.4 & $59.99 * *$ \\
\hline & Relative Profitability (\%) & 155.94 & 36.43 & 119.51 & 328.05 & $22.46 * *$ \\
\hline & B/C Ratio & 1.74 & 1.19 & 0.55 & 46.22 & $16.34 * *$ \\
\hline & Producer Incentive $(\%)$ & 42.41 & 16 & 26.41 & 156.1 & $42.25 * *$ \\
\hline & Value Added (LE/Fed) & 7666 & 4478.2 & 3187.2 & 77.18 & $27.24 * *$ \\
\hline & Productivity for $1000 \mathrm{~m} 3$ (Ton) & 7.41 & 6.37 & 1.04 & 16.33 & $10.26 * *$ \\
\hline & Return on Invested Pound (LE) & 0.74 & 0.19 & 0.55 & 289.5 & $16.34 * *$ \\
\hline \multirow{8}{*}{ 。ี } & Yield/Fed (Ton) & 15.25 & 13.15 & 2.1 & 15.98 & $10.7 * *$ \\
\hline & Net Return (LE/Fed & 20476 & 16266 & 4210 & 25.88 & $41.51 * *$ \\
\hline & Relative Profitability (\%) & 910.45 & 563.03 & 347.42 & 61.7 & $20.03 * *$ \\
\hline & B/C Ratio & 4.76 & 3.67 & 1.09 & 29.7 & $16.75 * *$ \\
\hline & Producer Incentive (\%) & 78.98 & 72.76 & 6.22 & 8.55 & $23.97 * *$ \\
\hline & Value Added (LE/Fed) & 23676 & 19466 & 4210 & 21.63 & $36.3 * *$ \\
\hline & Productivity for $1000 \mathrm{~m} 3$ (Ton) & 6.15 & 5.3 & 0.85 & 16.04 & $12.02 * *$ \\
\hline & Return on Invested Pound (LE) & 3.76 & 2.67 & 1.09 & 40.82 & $16.75 * *$ \\
\hline \multirow{8}{*}{ 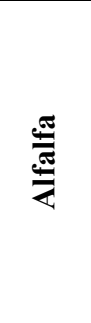 } & Yield/Fed (Ton) & 38.75 & 29.75 & 9 & 30.25 & $12.23 * *$ \\
\hline & Net Return (LE/Fed & 20525 & 13925 & 6600 & 47.4 & $33.7 * *$ \\
\hline & Relative Profitability (\%) & 1140.2 & 663.1 & 477.18 & 71.96 & $16.23 * *$ \\
\hline & $\mathrm{B} / \mathrm{C}(\%)$ & 4.11 & 3.02 & 1.09 & 36.17 & $13.4 * *$ \\
\hline & Producer Incentive (\%) & 75.67 & 66.87 & 8.8 & 13.16 & $20.05 * *$ \\
\hline & Value Added (LE/Fed) & 25995 & 19365 & 6630 & 34.24 & $32.7 * *$ \\
\hline & Productivity for $1000 \mathrm{~m} 3$ (Ton) & 13.14 & 10.08 & 3.06 & 30.36 & $20.03 * *$ \\
\hline & Return on Invested Pound (LE) & 3.11 & 2.02 & 1.09 & 54.01 & $13.4 * *$ \\
\hline
\end{tabular}

Source: Calculated from research experiment data.

** Significant at $1 \%$

Column $3=$ Column $(1)-$ Column (2), \% Change $=\frac{\text { Column(13) }}{\text { Column (2) }} \times 100$ 
indicating that the economic and productive efficiency of farms used fishpond water as main source of fertilization was higher than those for chemical fertilizers in production of such crops as indicated in table (3).

\subsection{Value Added}

The results in Table (3) showed that there is a statistically significant difference between average value added for sugar beet, onion and Alfalfa cultivated using fishpond water as main source of fertilization and that for using chemical fertilizers. The average value added for earlier mentioned crops used for fish pond water is about LE 7,666 per feddan, LE 23,676 per feddan and LE 25,995 per fed respectively. Whereas, this average for chemical fertilizer fields accounted about LE 4,478.3 per feddan, LE 19,466 per feddan and LE 19,365 per feddan respectively, representing a value added increment in fishpond water irrigated fields than those used chemical fertilizers by about $71.2 \%$, $21.6 \%$ and $34.2 \%$ respectively. In other words, this indicated an increase in the economic efficiency of farms used fishpond water as main source of fertilizer than those farms used chemical fertilizers in producing such crops.

\subsection{Productivity of water unit}

There is a statistically significant variation in average return per $1000 \mathrm{~m}^{3}$ of water for crops used fishpond water and their residuals as main source of fertilizer and those used conventional irrigation water. The average return per $1000 \mathrm{~m}^{3}$ for sugar beet, onion and Alfalfa cultivated using fishpond water reached about 7.4 ton, 6.2 ton and 13.1 ton respectively, while this average for conventional irrigation water fields chemically fertilized accounted about 6.4 ton, 5.3 ton and 10.1 ton respectively. This increment represents about $16.3 \%, 16.0 \%$ and $30.4 \%$ for crops used chemical fertilizers. This indicates that the productive efficiency of farms used fishpond water and their residuals as main source of fertilization is higher than farms used chemical fertilizers as indicated in table (3).

4.9. Effect of the use of fish water on the quality of agricultural land.

4.9.1. The impact of chemical fertilizers usage on reduction of agri-land grading

Table (4) illustrated agricultural land productivity trend all over Egypt during the periods (1996-2000) and (2006-2010). It depicted a noticeable increase during the second period (20062010) in number of centers and cultivated areas. On the other hand, there is a fall in first and fifth categories of productivity during the second period (2006-2010) than the first (1996-2000). The decline in first productivity category is presumably due to the cultivation of the land with the same crop more than once and the use of chemical fertilizers, which leads to deterioration and the transfer of these areas from the first productivity category to the second and third categories (Agricultural Land Resources Classification Bulletin according to Field Crops, 2005/2010).

5.2. The impact of using fish farm water in the reduction of heavy metals concentration in agricultural soils.

Relying on the obtained results, it is evident from Table (5) the importance of extending this experience all over Egypt to maximize the utilization of water resource, in addition to the production of healthy clean food free of pollution and maintaining the fertility of agricultural land as a result of reducing the concentration of residuals of heavy elements. This result is in line with what argued by (Younis 2009), that heavy elements resulted from the usage of chemical fertilizers cause deadly diseases such as liver diseases, kidney failure and cancer.

\section{SUMMARY AND RECOMMENDATIONS}

Due to scarcity of water resources in Egypt and the expansion of the fish farms as a way to obtain necessary animal protein to cope with the gradual population increase, it is a must to maximize the utilization of water resource. In particular, in fish farms as they depend mainly on water, where it would be considered a waste if not used in the cultivation of agricultural crops in addition to exploit fish residuals and wastes as a vital fertilizer to overcome the high prices of chemical fertilizers from one hand and to lower the disposal of chemical residuals in soil and cultivated output on the other hand. Chemical fertilizers residuals lead to deteriorate and lower agricultural land grading, as well as, the spread of harmful diseases that infect humans and animals, moreover, the use of chemical fertilizers escalates crop production costs. In response to these problems, the National Water Research Center - Wadi El-Natroun Research Station conducted a twofold research experiment for reusing fish farms waters in irrigating sugar beet, onion and Alfalfa and to be a supplier for nitrogenous fertilizer as a safer alternative to chemical fertilizer. The result of this experiment was promising showing the following:

It is estimated about 13.63 billion cubic meters of fish water farms have been reused in the cultivation of research experiment crops namely sugar beets, onions, and Alfalfa, where it is possible to save annually about 2.05 million ton of nitrogenous fertilizers estimated at about LE 6.15 billion.

Production and economic indicators results showed a superiority in all such indicators for fish water irrigated fields compared to conventional irrigated, where, productivity per feddan of sugar beet, onion, and Alfalfa reached an increase of $16.3 \%, 15.97 \%$ and $30.25 \%$ (on average) respectively, whereas, in terms of net returns 
the earlier mentioned outputs showed a significant increase by about $249.4 \%, 25.9 \%$ and $43.4 \%$ (on average) respectively, while for relative profitability the raise reached $328.0 \%, 61.7 \%$ and $21.9 \%$ (on average) respectively, whereas the benefit cost ratio raised by about $46.2 \%, 29.7 \%$ and $24.4 \%$ (on average) respectively, meanwhile, for returns per invested pound increased by, $289.5 \%$ for $40.8 \%$ and $35.7 \%$ (on average) respectively, in addition, for grower incentive the raise reached about $156.1 \%, 8.6 \%$ and $9.2 \%$ (on average) respectively. While, for average value added the increment recorded $71.2 \%, 21.6 \%$ and $31.5 \%$ (on average) respectively and finally it reached about $16.3 \%$, $16.04 \%$ and $30.36 \%$ (on average) respectively for average yield per 1000 cubic meter of water. It is worth mentioning that, soil analysis for fishpond water irrigated fields assured a reduction in heavy elements concentration compared to conventional chemically fertilized fields.

However, the study recommends the following: (1) expanding the use of fish farm water to irrigate agricultural crops to benefit from the above illustrated advantages in old and new lands, and estimating the possibility of generalizing such treatment (in terms of types of lands and/or suitable crops for generalization). (2) the need to estimate the benefits of experiment generalization in terms of maintaining the quality of agricultural land and reducing heavy residuals in terms of their impact on the reduction of deadly diseases such as liver diseases, kidney failure and cancer.

Table 4: Trends of the land fertility at the level of the Republic as an annual average for the period (1996-2000), (2006-2010)

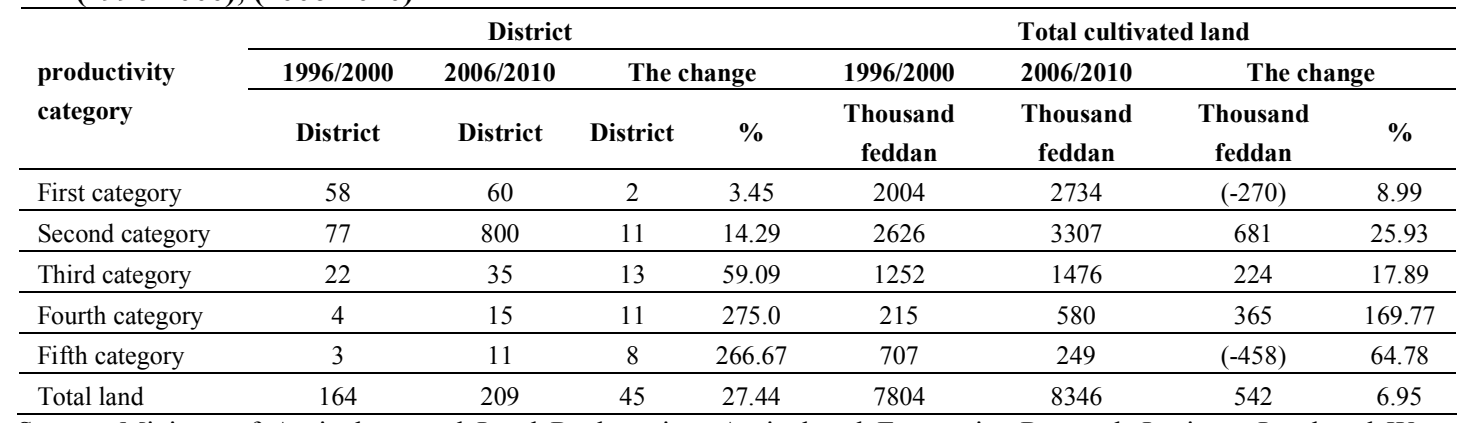

Source: Ministry of Agriculture and Land Reclamation, Agricultural Economics Research Institute, Land and Water Research Department, Agricultural Land Resources Classification Bulletin according to Field Crops, 2005/2010.

Table 5: The heavy metals (meg/l) before and after the experiment under different treatments.

\begin{tabular}{ccccccccc}
\hline \multirow{3}{*}{ Before } & Fertilizer types & Depth & Copper & Iron & Manganese & Nickel & Zinc \\
\cline { 2 - 9 } & \multirow{2}{*}{ control } & $0-20$ & 0.058 & 7.12 & 0.13 & 0.005 & 0.035 \\
\cline { 2 - 9 } & \multirow{2}{*}{$\begin{array}{l}\text { Chemical } \\
\text { fertilizers }\end{array}$} & $0-40$ & 0.108 & 7.54 & 0.157 & 0.008 & 0.039 \\
\cline { 3 - 9 } & & $20-40$ & 0.427 & 8.983 & 0.173 & 0.006 & 0.004 \\
\cline { 2 - 9 } & \multirow{3}{*}{ Fish pond water } & $0-20$ & 0.122 & 7.527 & 0.145 & 0.007 & 0.020 \\
\cline { 2 - 9 } & $20-40$ & 0.208 & 7.809 & 0.167 & 0.008 & 0.025 \\
\hline
\end{tabular}

Source: Ministry of Water Resources and Irrigation, National Water Research Center, Central Laboratories.

\section{REFERENCES}

Eid, A. M. S., 1993. Fish Nutrition, Rehabilitation Printing Press, Eltaahel printing, Ismailia, Egypt.

Maxwell, L. B., 1979. Farm Budgets from Farm Income Analysis to Agricultural Project Analysis. Published for the World Bank, The John Hopkins University Press, Baltimore and London.

Ministry of Agriculture and Land Reclamation, 2005. Agricultural Land Resources Classification Bulletin according to Field Crops, Agricultural Economics Research Institute, Land and Water Research Department.
Ministry of Agriculture and Land Reclamation, 2010. Agricultural Land Resources Classification Bulletin according to Field Crops, Agricultural Economics Research Institute, Land and Water Research Department.

Ministry of Agriculture and Land Reclamation, 2014. Fish Statistics Yearbook, General Authority for Fisheries Development.

Ministry of Agriculture and Land Reclamation, 2015. Fish Statistics Yearbook, General Authority for Fisheries Development.

Younis A. S. M., 2009. Economic Evaluation for Environmental Impacts of Organic Farming in Behira Governorate. Faculty of Agriculture (Damanhour) Alexandria University. 


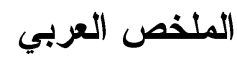

\section{دراسة اقتصادية لكفاعة استخدام الموارد المائية}

(در اسة حالة)

عبدالمجيد حسن عبدالمجيد عبدالمقصود'، هاله حسن عبد المجيد عبدالمقصود"، محمد عنتر محمد مرسى'

$$
\begin{aligned}
& \text { ' المركز القومى للبحوث المائية } \\
& \text { " قسم الاقتصاد الزراعى، كلية الزر اعة، لجامعة المنوفية }
\end{aligned}
$$

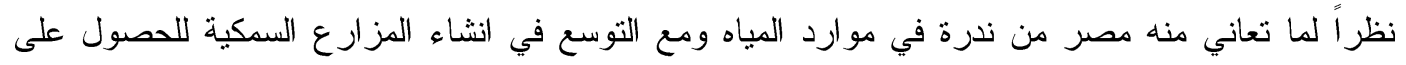

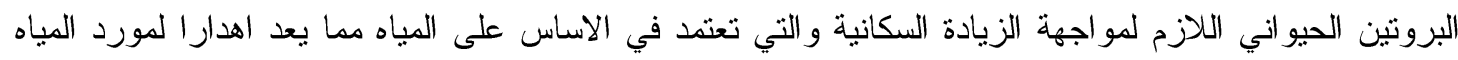

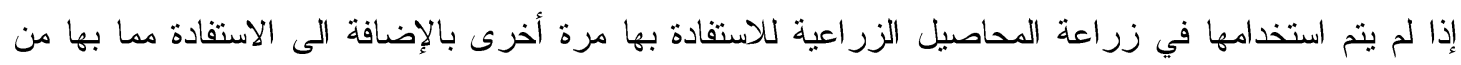

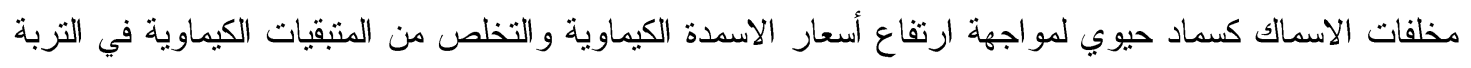

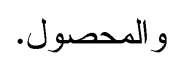

لذا فقد هدفت الدراسة إلى تعظيم الاستفادة من وحدة المياه بإعادة استخدام مياه المزارع السككية لرى المحاصيل

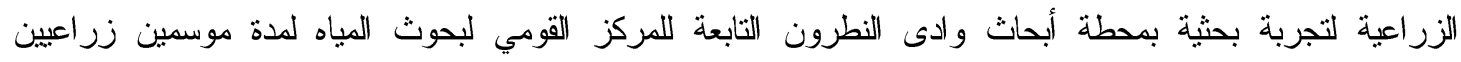

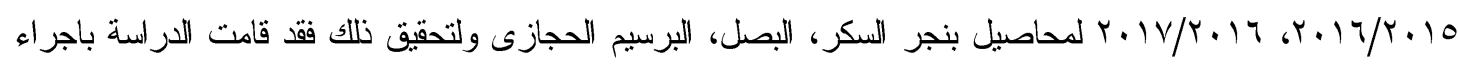

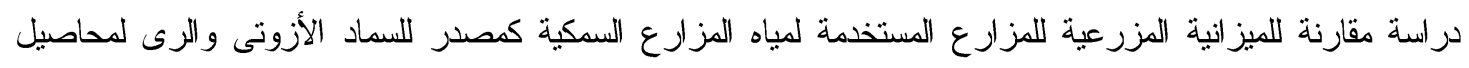

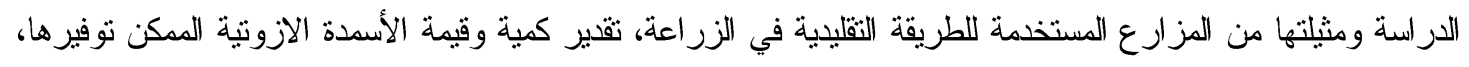

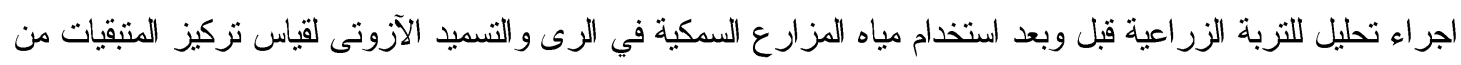

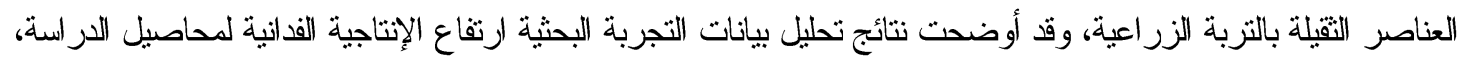

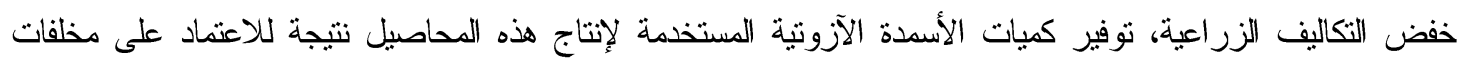

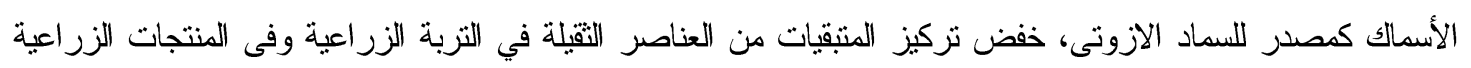

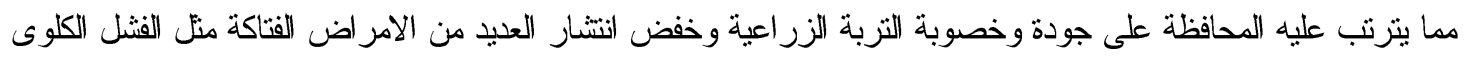
وامر اض الكبد والسرطانات. 